\title{
Investigation of the Ceiling Fixtures Design Evolution and LED Light Bar Alternative Concept Design Formation
}

\author{
Yevhenii Lobanov (D), and Glib Petchenko \\ O. M. Beketov National University of Urban Economy in Kharkiv, Kharkiv, Ukraine
}

\author{
Article History \\ Received: \\ 02 February 2021 \\ Accepted: \\ 25 April 2021 \\ Published online: \\ 30 April 2021 \\ Keywords \\ Ceiling Fixtures; \\ Light Intensity \\ Distribution Curve; \\ Cosine Light \\ Distribution; \\ LED Light Bars; \\ Equally Bright \\ Surface
}

\begin{abstract}
The purpose of the work is to study the development of concepts and technologies for the manufacture of ceiling fixtures to light the interior of buildings - office, public and administrative ones, etc. It is known that fluorescent lamps have long been used for interior lighting. Massive diffusers made of matte polycarbonate sheets were used to smooth the light intensity curve of such luminaires and bring it to the cosine light distribution. Due to the matte coating of the dif-fuser, the luminous part of the light fixtures acquired, with a fairly good approximation, the properties of an equally bright surface. Such surfaces are known to have a cosine light distribution and are very convenient for lighting. In the early 2000s, the problem of energy saving worsened, which led to a significant reduction in the number of luminaires of this type. These changes have also affected the approaches to the design of indoor light fixtures. The major difference of the new modifications of fluorescent fixtures is the absence of a matte reflector, which is very uneconomical in terms of energy saving, since it significantly decreased the luminous flux. The refusal to use the diffuser led to the emergence of fluorescent fixtures with a specular reflection system and shutters, which limited the dazzling effect of such lamps. However, with the parallel development of LED technology, the concept of choosing a light source in indoor lighting fixtures began to change. In grille fixtures, LEDs were gradually replacing fluorescent ones. Nowadays, manufacturers' websites offer a fairly wide selection of LED fixtures. They differ in the price, quality of LEDs used, design and technological solutions. Recently, the volume of production and range of LED light bars has been increasing. The article presents an attempt to consider which fixtures offered on the modern market are the most balanced in terms of engineering solution in the context of lighting, op-erational, pricing, technological and certification characteris-tics. Based on the analysis of fixtures of different types and modifications, the authors concluded that the most optimal engineering solution is ceiling LED light bars and developed a method of their design and certification.
\end{abstract}

\section{INTRODUCTION}

Modern lighting engineering involves the study of three main areas. These are radiation sources (lamps and lighting devices), the environment in which radiation propagates (optical elements of which complex optical systems of modern devices are composed) and radiation detectors. As for the study of optically transparent media, this is, as a rule, research in the field of applied optics, for example, in [1-6], as well as in various areas of solid-state physics (for example, acoustic defectoscopy of crystals at mechanical, structural and thermal studies of solids [7-12], radiation materials science [13-15]). Among the works in the field of studying the im- provement of the efficiency of radiation detectors for lighting engineering, in our opinion, the works devoted to the trap-detector technology [16-18] come to the fore. As for the direction of studying radiation sources and creating new lighting devices, it is most focused on direct production and is associated with the tasks of indoor and outdoor lighting [19-24].

Recently, there has been a massive transition of lighting devices to LED sources [25-28]. Due to the fact that a huge number of engineering solutions for luminaries for various purposes have appeared, there is an urgent need to understand the advantages and disadvantages of the proposed modifications of lighting devices and make weighted recommendation conclusions.

Corresponding author: gdaeron@ukr.net (Glib Petchenko)

(C) 2021 The Author(s). Published by O. M. Beketov National University of Urban Economy in Kharkiv

Use permitted under Creative Commons Attribution 4.0 International (CC BY 4.0)

Cite as: Lobanov, Y., \& Petchenko, G. (2021). Investigation of the ceiling fixtures design evolution and LED light bar alternative concept design formation. Lighting Engineering \& Power Engineering, 60(1), 1-8. https://doi.org/10.33042/ 2079-424X.2021.60.1.01 
The purpose of this work is to study the issue of creating the most efficient ceiling recessed luminaries, which are widely used in modern indoor lighting projects.

\section{FLUORESCENT GRILLE CEILING FIXTURES AND AN ATTEMPT TO REPLACE THEM WITH LED ONES}

Due to low energy efficiency of luminaries with matte diffusers, the first modifications of fluorescent grille light fixtures appeared in the early 2000s. The design and light intensity distribution curve of one of them are shown in Fig. 1.

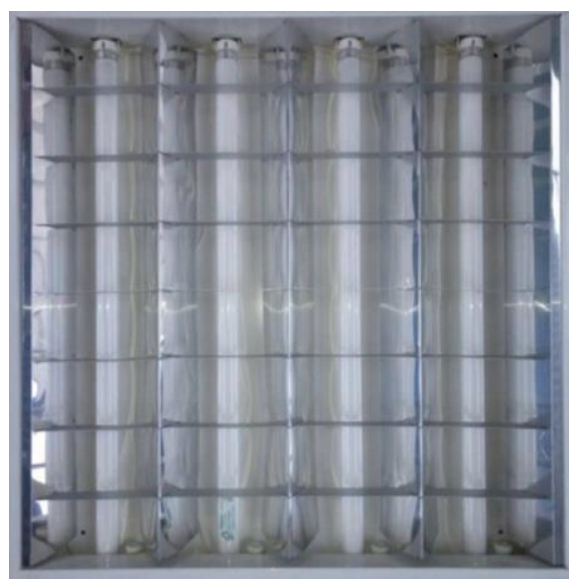

(a)

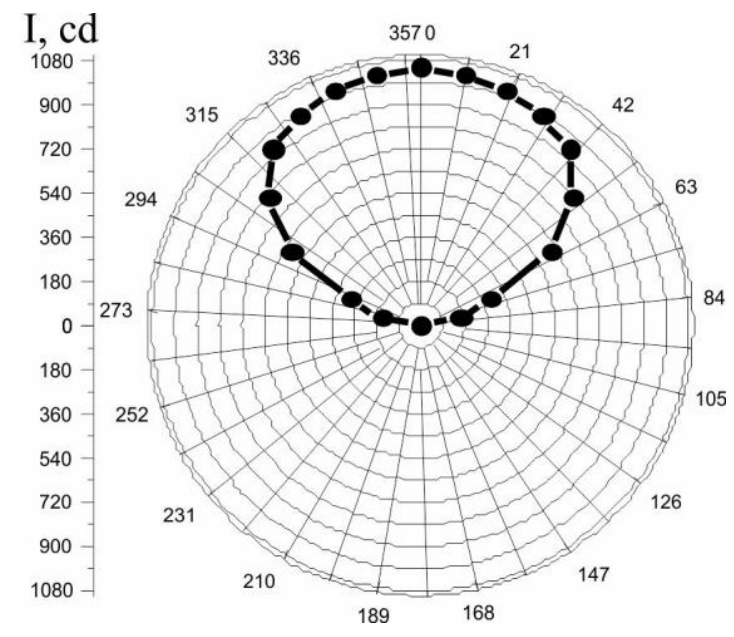

(b)

Figure 1. Design (a) and light intensity distribution curve (b) of a fluorescent grille light fixture

Structurally, it consists of a housing, specular reflector and a series of 7 shutters - plates attached to the reflector. The analysis of these basic structural elements showed that cold stamping methods cutting, punching, and bending - are employed for their production. The material used is rolled aluminum. You can see that the light fixture is designed for four fluorescent lamps, in our case, with a total power of $72 \mathrm{~W}$. To measure the light intensity, we applied a photometer. The distribution curve obtained is also shown in Fig. 1.

As can be seen, the light distribution curve of this type of light fixtures, in fact, is similar to the cosine light distribution of those with equally bright matte diffusers. However, unlike them, there is no loss of luminous flux when the light passes through the diffuser layer, so the energy efficiency of such a lamp is much higher. After the appearance of the first LEDs, we observed an attempt to replace fluorescent lamps with LED ones. A photo of a modified grille lamp is shown in Fig. 2. The luminous flux emitted by such a lamp was almost the same as that of the fluorescent grille $\sim 3103 \mathrm{~lm}$, while the power of the luminaire was about twice less. As for checking the light distribution of the lamp with the help of a distribution photometer, its light intensity curve demonstrated a worse approximation to D-type curve. In our opinion, the deterioration of the light distribution occurred due to the deep embedding of individual LEDs into the reflector surface. The fact is that the side plates of the reflectors roughly correspond to the cross section of fluorescent lamps, and their luminous side surface is effectively reflected by the specular reflection system, which is characteristic of the luminaire in Fig. 2.

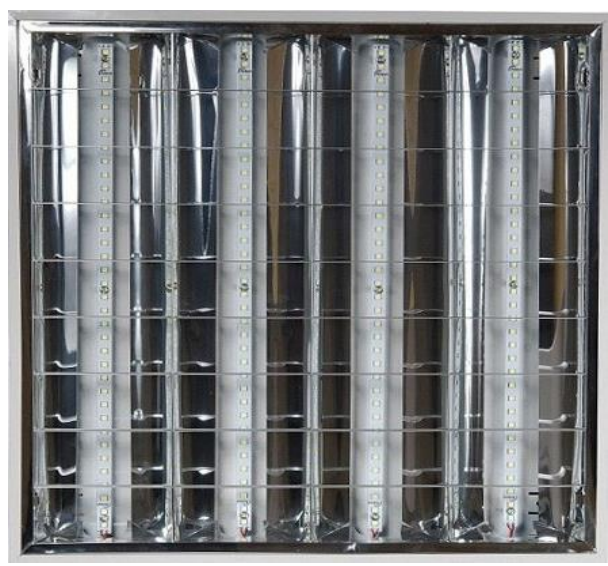

Figure 2. Replacement of fluorescent lamps with LED ones in a grille light fixture

The design of a grille light fixture shown in Fig. 2, in our opinion, is also inconvenient in terms of its operation and replacement of light sources that have exhausted their life. Obviously, the replacement is not possible without special tools. As for the technologies employed to make the light fixture, it is clear that they are almost similar, except for some differences associated with the use of other types of light sources.

Obviously, the above-mentioned shortcomings contributed to the emergence of new modifications of grille light fixtures, one of the designs of which is shown in Fig. 3. The design and technical data are taken from the open site of the manufacturer JSC Vatra [29]. 


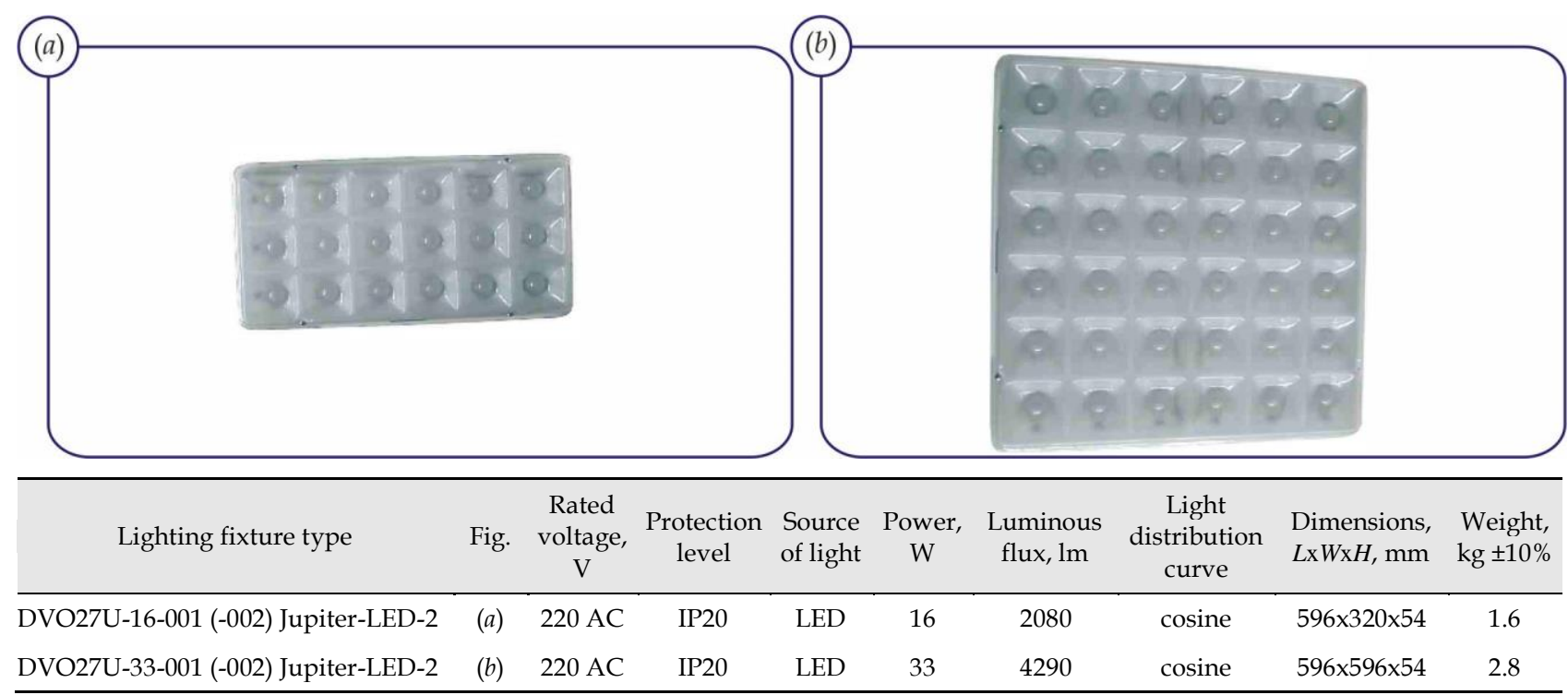

Figure 3. Design and technical characteristics of a modern grille light fixture produced by JSC Vatra [29]

This light fixture, as you can see, has a number of advantages. Its weight is reduced by about half compared to traditional grille lamps. The light fixture itself, being a replacement similar to 4 fluorescent lamps, is energy efficient - its power is only $33 \mathrm{~W}$, although its flux is almost one and a half times greater than that of the fluorescent one. Moreover, we see that the manufacturer uses the light distribution of D-type, which corresponds to the cosine distribution. There are no shutters here, their role is performed by the dimpled surface of the reflector, which is a matte light-stabilized polycarbonate. The basis for mounting the reflector is sheet steel. The control equipment and LEDs are manufactured by Osram, which guarantees high quality lighting, technical and operational characteristics of the proposed lighting device. Actually, the above design would fully meet all the requirements for this type of product, if not for the alternating brightness of the luminous surface, which is inherent in all grille lamps which once replaced those with matte diffusers.

\section{LED CEILING LIGHT BARS}

Recently, ceiling fixtures based on LED bars have become widely used. The photo of one of such luminaries, variants of its installation, its assortment and technical characteristics of its various modifications, taken from the open site of the manufacturer of JSC Vatra, are given in Fig. 4.

It is easy to see that in terms of lighting parameters, simplicity of construction, technical and operational characteristics, this light fixture is the most successful and balanced design solution. One of its main advantages, in our opinion, is its equally bright luminous surface.

\section{METHOD FOR CERTIFICATION TESTS AND DESIGN OF LED CEILING LIGHT BARS}

After designing a light fixture, any manufacturer goes to its testing, in particular, studying its light distribution. Such testing is either performed with the help of their own experimental equipment or in independent photometric laboratories. Any lighting device is certified for compliance with the conditions of its future operation.

The value of the considered design, in our opinion, lies mainly in the fact that light fixtures of this type do not require complex laboratory equipment. To receive its light intensity distribution curve, which allows to get the luminous flux of the light fixture (using the zonal solid angle method) and its other certification characteristics, it is enough to conduct one simple experiment employing a luxmeter. As it is known, the errors of modern luxmeters do not exceed $5 \%$, so there is every reason to expect obtaining sufficient and reliable experimental data.

The simple theoretical method, proposed by us in this paper to check the light distribution and design of the lamp, is based on the fact that the LED bar presents an equally bright surface.

\section{For the certification test}

If the surface luminance is measured with a photometer at zero distance (i.e., close measurement in case of a luxmeter), it will be true that $M=E$ (i.e., the surface luminance $M$ will pass into the illuminance $E$ on the luxmeter).

Considering that the surface is evenly bright (by the way, we recommend to pre-check it with the same luxmeter, measuring the illuminance closely at different points of the luminous surface) and with regard to all above-mentioned, equation (1) is true: 


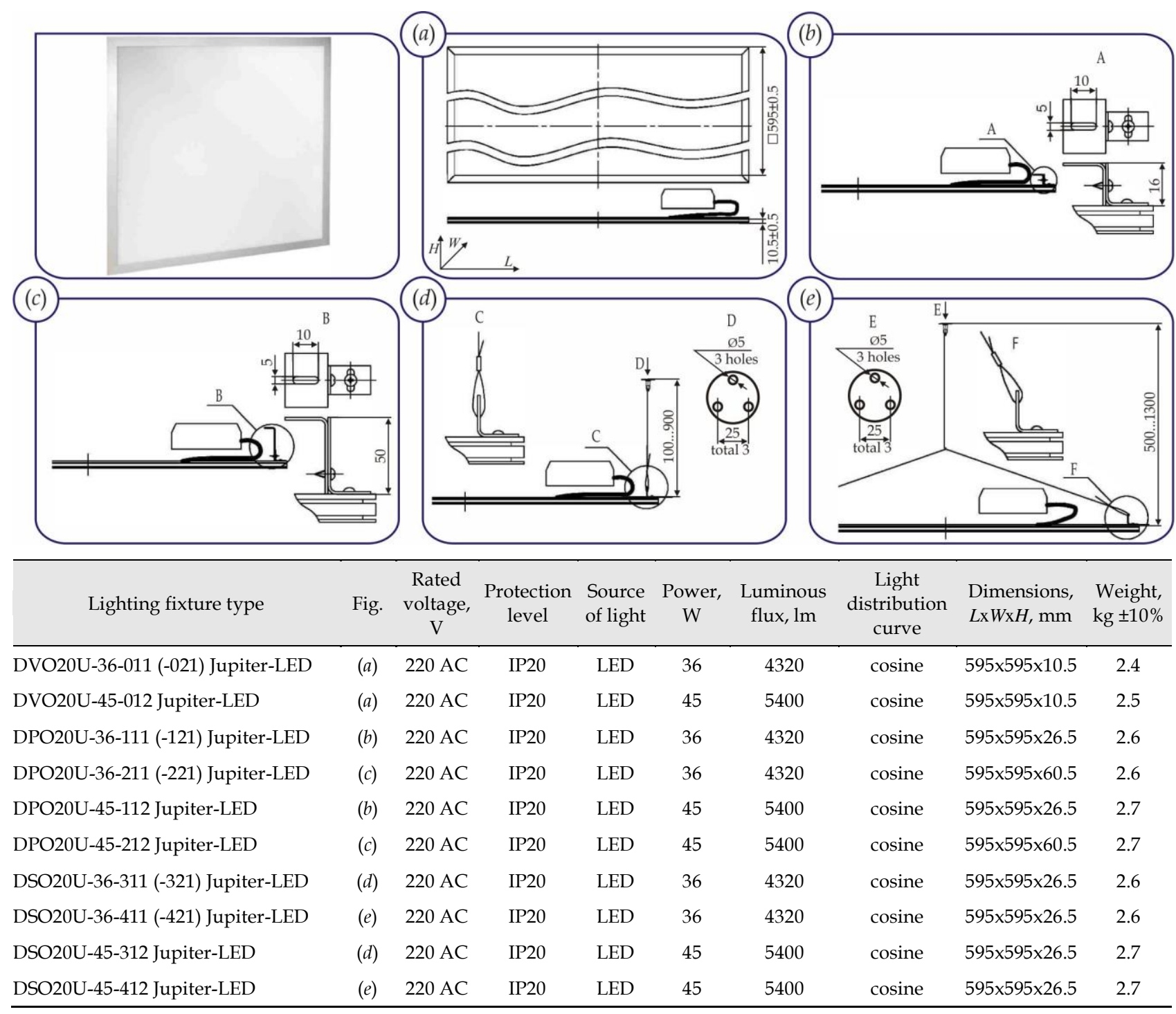

Figure 4. Design and technical characteristics of the modern LED light bars of JSC Vatra [29]

$M=\pi \cdot L=E$.

Hence the surface brightness $L$ (which is the same at all points of the luminous surface) can be calculated using the data obtained during our simple experiment to measure illuminance:

$L=E / \pi$.

The luminous intensity in any direction is [30]:

$I(\alpha)=L \cdot A_{\text {projection }}$,

where $A_{\text {projection }}$ is the area of projection of the luminous body in the selected direction of observation, the angle between which and the normal line to the calculated surface is the value of $\alpha$.

Since the surface is equally bright, for any direction of $\alpha$ :

$$
A_{\text {projection }}=A_{\text {luminous body }} \cdot \cos \alpha \text {, }
$$

where $A_{\text {luminous body }}$ is the area of the luminous sur- face (in our case, the area of a square with a geometry of approximately $600 \times 600 \mathrm{~mm}^{2}$ - the standard size of a cell of a suspended ceiling), $L$ is the brightness of the surface. In view of this, we have:

$I(\alpha)=L \cdot A_{\text {projection }}=\frac{E}{\pi} \cdot A_{\text {luminous body }} \cdot \cos \alpha$.

This simple formula obtained by us directly proves that the light intensity distribution curve of any light bars with an equally bright surface is a purely cosine one. To check the light distribution of any light fixture of this type, we recommend a simple algorithm.

1) Check the compliance with the condition of equal brightness of the surface (measuring illuminance at a series of control points).

2) With a slight deviation of the results of individual measurements from the average value of the measured illuminance, we recommend to process the experimental data according to the standard method of processing results of 
direct measurements and find the average value of $E$.

3) Calculate the geometry of the luminous body.

4) Calculate the light intensity distribution curve of the device using formula (5), and its luminous flux using the zonal solid angle method.

\section{For design}

By definition, with a known luminous flux of the light fixture, we can calculate the surface luminance by the formula [30]:

$$
M=\Phi / A_{\text {luminous body }} \text {. }
$$

Given the equal brightness of the surface and the ratio (1), we have:

$$
L=\frac{\Phi}{\pi \cdot A_{\text {luminous body }}} \text {. }
$$

Considering relations (3), (7) and (4), we can write down the following equation:

$$
I(\alpha)=\frac{\Phi}{\pi A_{\text {luminous body }}} \cdot A_{\text {luminous body }} \cos \alpha=\frac{\Phi}{\pi} \cos \alpha \text {. }
$$

An interesting consequence of formula (8) is that the light intensity of this type of light fixtures does not depend on the area of the luminous surface, but depends only on the luminous flux. Let's analyze what the flux may depend on. First, it is the greater the greater the luminous flux of each of the LEDs installed around the perimeter of the side surface of the ceiling is. Secondly, it directly depends on the number of LEDs $N$. And thirdly, it depends on the transmittance of the $\tau$ polymer, to the butt end of which the light from the LED linear is directed. Based on these simple considerations, we can derive the following simplified formula:

$\Phi \sim \tau \cdot N \cdot \Phi_{\text {one } L E D}$

where $\Phi$ is the luminous flux of one LED.

The formula we received shows how simple and beautiful the process of designing this type of light fixtures is. To obtain the required light intensity distribution curve, we need to monitor only three characteristics, namely, the luminous flux of one LED, the number of LEDs, $N$, and the optical characteristics (transmittance $\tau$ ) of the polymer material used for the diffuser. Using the theoretical algorithm proposed, we, as an illustration, performed the calculations and built the light intensity distribution curve of the light fixture, the technical characteristics of which are shown in Fig. 4. The calculations were made for 3 modifications of this light fixture (the first three rows in the table of technical characteristics presented in Fig. 4) - for the flux of $4320 \mathrm{~lm}$ ). The obtained light intensity distribution curve is shown in Fig. 5.

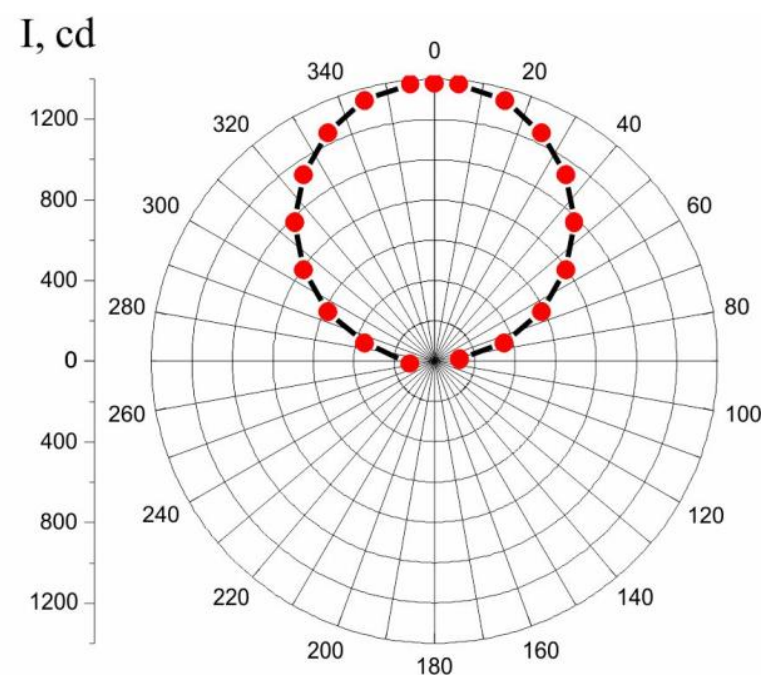

Figure 5. Light intensity distribution curve of the LED light bar DVO20U-36-001 (-011, -021) Jupiter-LED

The measurements were performed for a similar lamp produced by another manufacturer, using the GO-2000H goniophotometer developed by the Research Center for Lighting Measurements at O. M. Beketov National University of Urban Economy in Kharkiv. The results obtained completely proved (Fig. 6) the validity of our simple method of calculating the light intensity distribution curve of the light bar.

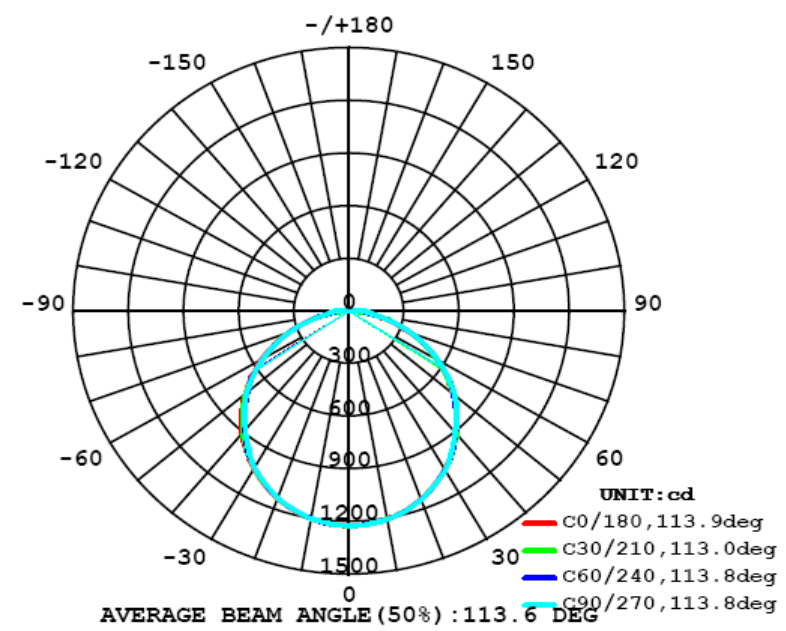

Figure 6. Light intensity distribution curve of the LED light bar built using the GO-2000H goniophotometer developed by the Research Center for Lighting Measurements at O. M. Beketov National University of Urban Economy in Kharkiv

We do not provide the data concerning the manufacturer as well as the power, name, and design of the light fixture examined using a goniophotometer GO-2000H since this information is a trade secret. But we present some results of this study simply as an illustration of the validity of our judgments and the proposed by us theoretical basis for calculation. 
Therefore, we can see that our calculations give accurate results, not only qualitative but also practical and quantitative ones. This testifies to the viability of the proposed theoretical foundations expressed by the above formulas. It can be seen that state-of-the-art world-class photometric equipment provides a clear cosine light distribution for the LED light bars. Isoluxes and isocandels, which are also provided in the photometric report (see Fig. 7,8) also confirm our ideas about the photometric body of the LED light bars.
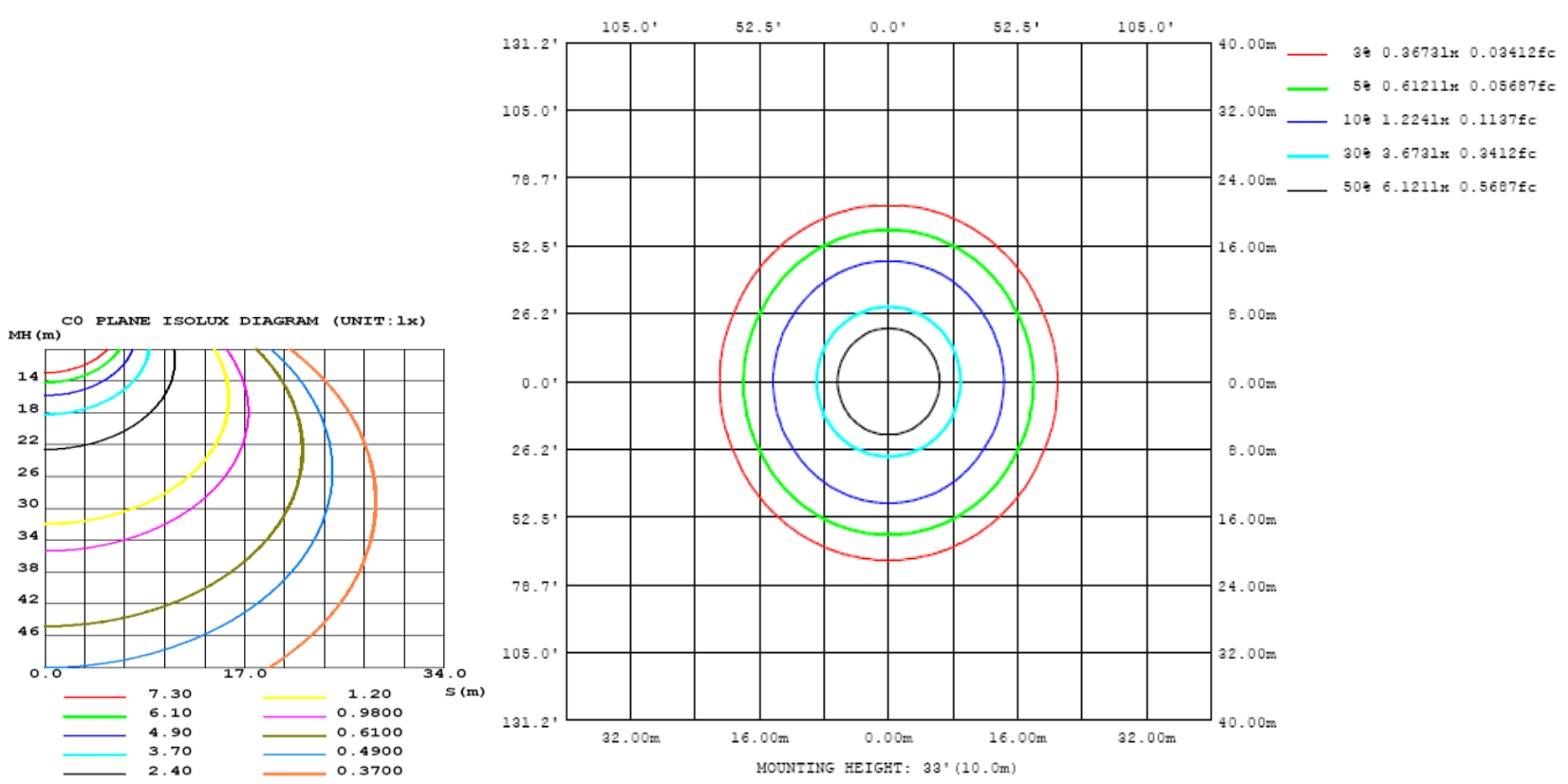

Figure 7. Isoluxes of the LED light bars measured using the GO-2000H goniophotometer developed by the Research Center for Lighting Measurements at O. M. Beketov National University of Urban Economy in Kharkiv

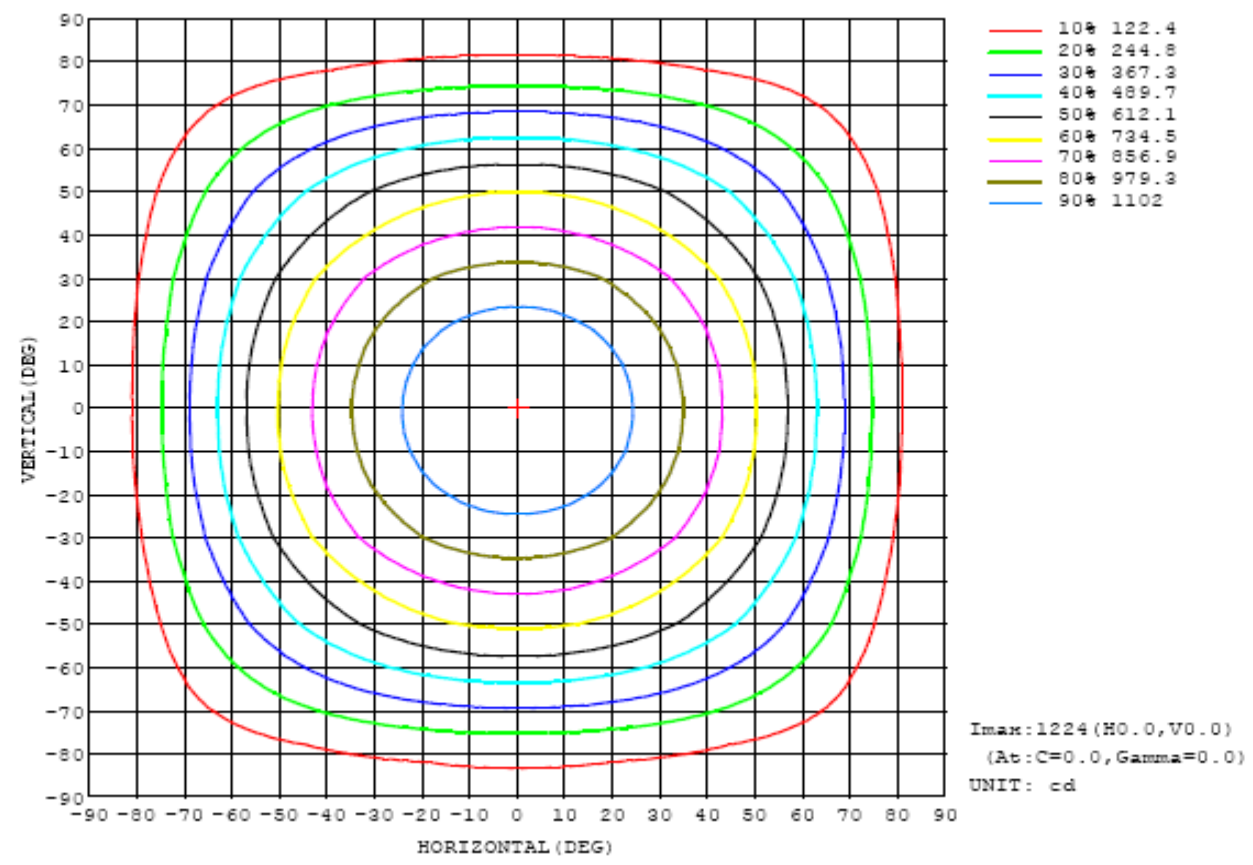

Figure 8. Isocandels of the LED light bars measured using the GO-2000H goniophotometer developed by the Research Center for Lighting Measurements at O. M. Beketov National University of Urban Economy in Kharkiv

\section{CONCLUSIONS}

The evolution of the development of ceiling fixtures over the last 20 years is considered. The gradual change of the design concept of grille lamps in the situation of transition from fluorescent lamps to
LEDs is shown. The method of design and attestation tests of light bars is presented, also the results of theoretical calculation in comparison with the result of photometric testing of a similar light on the GO-2000H goniophotometer developed by the Research Center for Lighting Measurements at 
O. M. Beketov National University of Urban Economy in Kharkiv. There is a good agreement between theory and experiment.

\section{DISCLOSURE STATEMENT}

No potential conflict of interest was reported by the author(s).

\section{REFERENCES}

1. Bezugly, A.V., \& Petchenko, A.M. (2018). Photon flow density distribution in the diffraction pattern of single- and two parallel slits. Telecommunications and Radio Engineering, 77(1), 77-82. https://doi.org/10.1615/Tele comRadEng.v77.i1.80

2. Besougly, A.V., \& Petchenko, O.M. (2015). Diffraction of obliquely incident electrons from a grating of infinitely thin strips. Telecommunications and Radio Engineering, 74(3), 239-245. https://doi.org/10.1615/TelecomRadEng. v74.i3.60

3. Lukin, K.A., Tatyanko, D.N., \& Pikh, A.B. (2016). Application of optical spectral interferometry for thin film thickness measurement. In 2016 9th International Kharkiv Symposium on Physics and Engineering of Microwaves, Millimeter and Submillimeter Waves (MSMW) (pp. 1-3). IEEE. https:/ / doi.org/10.1109/MSMW.2016.7538130

4. Yakovlev, V., Trefilova, L., Lebedinsky, A., Daulet, Z., \& Dubtsov, I. (2016). Time-resolved spectroscopy of CsI $\left(\mathrm{CO}_{3}\right)$ scintillator. Journal of Luminescence, 173, 34-37. https://doi.org/10.1016/j.jlumin.2015.12.044

5. Yakovlev, V., Trefilova, L., Lebedynskiy, A., Karnaukhova, A., \& Alekseev, V. (2017). Peculiarities of intrinsic luminescence excited by pulsed electron beam in CsI and CsI:CO $\mathrm{CO}_{3}$. Journal of Luminescence, 190, 267-271. https://doi.org/10.1016/j.jlumin.2017.05.044

6. Yakovlev, V., Trefilova, L., Alekseev, V., Karnaukhova, A., Shpylynska, O., Lebedynskiy, A., \& Tarakhno, O. (2018). Influence of color centers on the luminescent response of radiation-damaged CsI:Tl crystal. Functional Materials, 25(1), 13-20. https:// doi.org/10.15407/fm25.01. 013

7. Lee, J., Ashokkumar, M., \& Kentish, S.E. (2014). Influence of mixing and ultrasound frequency on antisolvent crystallisation of sodium chloride. Ultrasonics Sonochemistry, 21(1), 60-68. https://doi.org/10.1016/j.ultsonch. 2013.07.005

8. Urusovskaya, A.A., Petchenko, A.M., \& Mozgovoi, V.I. (1991). The influence of strain rate on stress relaxation. Physica Status Solidi (a), 125(1), 155-160. https://doi.org/ 10.1002/pssa.2211250112

9. Alshits, V.I., Darinskaya, E.V., Koldaeva, M.V., \& Petrzhik, E.A. (2016). Resonance magnetoplasticity in ultralow magnetic fields. JETP Letters, 104(5), 353-364. https:/ / doi.org/10.1134/S0021364016170045

10. Guillon, O., Elsässer, C., Gutfleisch, O., Janek, J., Korte-Kerzel, S., Raabe, D., \& Volkert, C.A. (2018). Manipulation of matter by electric and magnetic fields: toward novel synthesis and processing routes of inorganic materials. Materials Today, 21(5), 527-536. https://doi. org/10.1016/j.mattod.2018.03.026
11. Alshits, V.I., Darinskaya, E.V., Koldaeva, M.V., Kotowski, R.K., Petrzhik, E.A., \& Tronczyk, P. (2017). Dislocation kinetics in nonmagnetic crystals: a look through a magnetic window. Physics-Uspekhi, 60(3), 305. https:/ / doi. org/10.3367/UFNe.2016.07.037869

12. Alshits, V.I., Darinskaya, E.V., Koldaeva, M.V., Kotowski, R.K., Petrzhik, E.A., \& Tronczyk, P.K. (2017). Experimental studies and computer simulations of magnetoplastic effect. Polish Journal of Applied Sciences, 2(1), 21-24. https://doi.org/10.19260/PJAS.2016.2.1.05

13. Petchenko, O.M., Petchenko, G.O., \& Boiko, S.M. (2021). Study of dynamic drag of dislocations in KCl crystals with impurities and different dislocation structure. Problems of Atomic Science and Technology, 132(2), 51-54 https:/ / doi.org/10.46813/2021-132-051

14. Petchenko, O.M., Petchenko, G.O., Boiko, S.M., \& Bezugly, A.V. (2020). The influence of x-ray irradiation on dynamical and structural characteristics of strained $\mathrm{NaCl}$ crystals. Problems of Atomic Science and Technology, 126(2), 23-26.

15. Petchenko, O.M., Petchenko, G.O., Boiko, S.M., \& Bezugly, A.V. (2020). Optical and colorimetrical characteristics of strained LiF crystals under X-ray irradiation. Problems of Atomic Science and Technology, 126(2), 60-63.

16. Litvinenko, A.S., \& Timofeev, E.P. (2010). Use of gangways-detectors for precision measurements. Lighting Engineering \& Power Engineering, 21(1), 20-23. (in Russian)

17. Tatyanko, D.N., Neyezhmakov, P.I., Timofeev, Y.P., Litvinenko, A.S., Suvorova, K.I., \& Didenko, O.M. (2019). Quantum efficiency improvement of optical radiation trap-detectors. Semiconductor Physics Quantum Electronics $\mathcal{E}$ Optoelectronics, 22(1), 104-110. https://doi.org/10. 15407/spqeo22.01.104

18. Weiss, P., Araújo, M.O., Kaiser, R., \& Guerin, W. (2018). Subradiance and radiation trapping in cold atoms. New Journal of Physics, 20(6), 063024. https://doi.org/10. 1088/1367-2630/aac5d0

19. Montoya, F.G., Peña-García, A., Juaidi, A., \& Manzano-Agugliaro, F. (2017). Indoor lighting techniques: an overview of evolution and new trends for energy saving. Energy and Buildings, 140, 50-60. https://doi.org/ 10.1016/j.enbuild.2017.01.028

20. Natephra, W., Motamedi, A., Fukuda, T., \& Yabuki, N. (2017). Integrating building information modeling and virtual reality development engines for building indoor lighting design. Visualization in Engineering, 5, 19. https:// doi.org/10.1186/s40327-017-0058-x

21. Kalustova, D., Kornaga, V., Rybalochka, A., \& Valyukh, S. (2020). Space of visual and circadian parameters of RGBW lighting systems. Lighting Engineering $\mathcal{E}$ Power Engineering, 57(1), 16-21. https://doi.org/10.33042/2079424X-2020-1-57-16-21

22. Salvadori, G., Fantozzi, F., Rocca, M., \& Leccese, F. (2016). The energy audit activity focused on the lighting systems in historical buildings. Energies, 9(12), 998. https://doi.org/10.3390/en9120998

23. Pracki, P., \& Skarżyński, K. (2020). A multi-criteria assessment procedure for outdoor lighting at the design stage. Sustainability, 12(4), 1330. https://doi.org/10.3390/ su12041330 
24. Gorgulu, S., \& Kocabey, S. (2020). An energy saving potential analysis of lighting retrofit scenarios in outdoor lighting systems: a case study for a university campus. Journal of Cleaner Production, 260, 121060. https:/ / doi. org/10.1016/j.jclepro.2020.121060

25. Bauer, M., Glenn, T., Monteith, S., Gottlieb, J.F., Ritter, P.S., Geddes, J., \& Whybrow, P.C. (2018). The potential influence of LED lighting on mental illness. The World Journal of Biological Psychiatry, 19(1), 59-73. https:// doi.org/10.1080/15622975.2017.1417639

26. Wlas, M., \& Galla, S. (2018). The influence of LED lighting sources on the nature of power factor. Energies, 11(6), 1479. https://doi.org/10.3390/en11061479
27. Kıyak, İ., Oral, B., \& Topuz, V. (2017). Smart indoor LED lighting design powered by hybrid renewable energy systems. Energy and Buildings, 148, 342-347. https:// doi.org/10.1016/j.enbuild.2017.05.016

28. Nardelli, A., Deuschle, E., de Azevedo, L.D., Pessoa, J.L.N., \& Ghisi, E. (2017). Assessment of Light Emitting Diodes technology for general lighting: a critical review. Renewable and Sustainable Energy Reviews, 75, 368379. https://doi.org/10.1016/j.rser.2016.11.002

29. Vatra. (2021). Office lighting. http://vatra.ua/ $\mathrm{ukr} /$ products/office-lighting

30. Meshkov, V.V. (1979). The basics of lighting engineering. Energiya. (in Russian)

\title{
Дослідження еволюції розвитку проектування стельових світильників і формування концепції проектування іx LED-панельного варіанту
}

\author{
Євгеній Лобанов, Гліб Петченко
}

\begin{abstract}
Анотація. Метою даної роботи є вивчення розвитку концепцій і технологій виготовлення стельових світильників для освітлення внутрішніх приміщень - офісних, громадських і адміністративних тощо. Як відомо, для задач внутрішнього освітлення тривалий час використовувались люмінесцентні лампи. Для вирівнювання КСС таких світильників і при-ведення ї̈ до косінусного світлорозподілу використовували масивні розсіювачі 3 матованого листового полікарбонату. Завдяки матованій поверхні розсіювача світня частина світильника набувала 3 досить непоганим наближенням властивостей рівнояскравої поверхні. Такі поверхні, як відомо відзначаються косінусним світлорозподілом і є дуже зручними для освітлення приміщень. На початку 2000-х років загострилась проблема енергозбереження, що призвело до скорочення значної частини парку світильників, що існував до того часу. Ці зміни позначились і на підходах до проектування світильників внутрішнього освітлення. Першою істотною відмінністю оновлених модифікацій люмінесцентних світильників нового покоління стала відсутність матованого відбивача, який дуже неекономно, 3 точки зору енергозбереження, затримував значну частину світлового потоку. Відмова від розсіювача призвела до появи люмінесцентних світильників з дзеркальною відбиваючою системою і затінювачами, що обмежувала сліпучу дію таких світильників. Однак, із паралельним розвитком світлодіодних технологій, стала змінюватись концепція щодо вибору джерела світла у світильниках внутрішнього освітлення. 3'явились вже перші заміни люмінесцентних ламп в растрових світильниках на світлодіодні. В наш час сайти виробників пропонують достатньо великий вибір щодо світлодіодних світильників. Світильники відрізняються за ціною, за якістю використаних світлодіодів, за конструктивними і технологічними рішеннями. Останнім часом збільшується обсяг виробництва і номенклатура панельних світлодіодних світильників. Задачею даної статті є намагання розібратися, які світильники, що пропонуються на сучасному ринку, є найбільш виваженими в плані інженерного рішення в контексті світлотехнічних, експлуатаційних, цінових, технологічних і атестаційних характеристик. На підставі аналізу світильників різних типів і модифікацій, автори роботи прийшли до висновку, що найбільш оптимальним інженерним рішенням є стельові панельні LED-світильники і розробили методику їх проектування і атестації.
\end{abstract}

Ключові слова: стельові світильники, крива сили світла, косінусний світлорозподіл, світлодіодні панелі, рівнояскрава поверхня.

\section{NOTES ON CONTRIBUTORS}

Yevhenii Lobanov

lobanov.kh@gmail.com

Glib Petchenko

gdaeron@ukr.net
Postgraduate student

Department of Alternative Electric Power and Electrical Engineering

O. M. Beketov National University of Urban Economy in Kharkiv, Kharkiv, Ukraine

(D) https://orcid.org/0000-0001-9807-2405

D.Sc., Professor

Department of Lighting Engineering and Lighting Sources

O. M. Beketov National University of Urban Economy in Kharkiv, Kharkiv, Ukraine

iD https://orcid.org/0000-0002-2069-5757

p https://publons.com/researcher/D-2174-2018

Chttps:/ / scopus.com/authid/detail.uri?authorId=6506147806 